\title{
Assessing the Seawater Intrusion Due to Beach Wells in the Desalination Plant
}

\author{
Yunes Mogheir \\ Environmental Engineering Department, Engineering Faculty, Islamic University of Gaza, Gaza, Palestine \\ Email: ymogheir@iugaza.edu.ps
}

How to cite this paper: Mogheir, Y. (2016) Assessing the Seawater Intrusion Due to Beach Wells in the Desalination Plant. Journal of Geoscience and Environment Protection, 4, 37-47.

http://dx.doi.org/10.4236/gep.2016.412003

Received: October 22, 2016

Accepted: December 5, 2016

Published: December 8, 2016

Copyright $\odot 2016$ by author and Scientific Research Publishing Inc. This work is licensed under the Creative Commons Attribution International License (CC BY 4.0).

http://creativecommons.org/licenses/by/4.0/ (c) (i) Open Access

\begin{abstract}
Short-Term Low Volume (STLV) Sea Water Desalination Plant of $6000 \mathrm{~m}^{3} / \mathrm{d}$ is under construction in the middle area of Gaza Strip. The plant will provide desalinated water for 75,000 inhabitants in regions in Khanyounis and Rafah. The intake of desalination plant will be indirectly from four beach wells. This article aims at providing the environmental impacts of these wells on the aquifer and the mitigation measures in case of negative impacts. In order to study the impacts of beach wells on the aquifer, a prediction groundwater three-dimensional model for the beach wells area, starting from the year 2000 until year 2030, was used. MODFLOW software was used for modeling the groundwater flow and SEAWAT software was used to model the seawater intrusion effect. The aquifer parameters were set as if they were in the transient model. The long term seasonal recharge rate for the summer and winter is considered to represent the seasonal differences in recharge through each year. The study showed that the steady four-meter drawdown in the beach wells will force the flow from the eastern direction to the sea. This will have positive impacts on the aquifer since it will decrease the seawater intrusion to the aquifer. The beach wells will pump water with $\mathrm{Cl}$ concentration equal to $18,000 \mathrm{mg} / \mathrm{l}$. This means that the beach wells will accelerate the flow from the aquifer to the sea direction but still the pumped water is considered as seawater. This indicates the positive impacts on the groundwater aquifer since it will decrease the seawater intrusion in the beach wells area (Gaza Strip Middle area). In conclusion, these beach wells in this desalination plant (small capacity) are safe for the groundwater aquifer and it will decrease the effect of seawater intrusion on the aquifer.
\end{abstract}

\section{Keywords}

Beach Wells, Aquifer, Seawater Intrusion, Chloride, Desalination 


\section{Introduction}

Various United Nations, bilateral and local agencies have continued with their efforts to identify solutions for water scarcity and salinity problems in Gaza strip. Several studies have been undertaken and plans and reports have been produced for interventions to address the potable water requirements of the people in the Gaza Strip which is recorded as one of the most heavily populated areas in the world [1].

At present the underground coastal aquifer represents the main source for water supply to the population of approximately 1.7 million living in Gaza. Minor volumes of fresh water (4.7 MCM/Year) are currently imported from Israel Mekorot Water Company in addition to other small amounts supplied from at least 13 existing (public) plants, for a total capacity of $7020 \mathrm{~m}^{3} /$ day, and including 8 plants installed with UNICEF assistance [2].

The latest registry and monitoring records showed that annual sustainable yield of the coastal aquifer within the geographical boundary of Gaza is estimated to be 55 Million Cubic Meters (MCM). Recent rates of pumping from the aquifer are estimated at $170 \mathrm{MCM} /$ year for both domestic and agricultural needs. The abstraction rates have increased significantly over the last three decades, due to a combination of inadequate available water imports to Gaza, the expanding population within Gaza, and the drilling and use of unlicensed wells (especially to provide irrigation for agricultural activities). Figure 1 showed that the over-abstraction has caused saline intrusion i.e. the entry of sea water to the aquifer from the Mediterranean Sea to the west, and also due to the lowering of the water table from deep groundwater abstraction to the south-east of Gaza by Israel. Water quality has been deteriorating rapidly, and modeling data suggest that the deterioration will continue further, with time [1] [2] [3].

Massive over-pumping has led to increased saline intrusion as seawater from the adjacent Mediterranean enters and contaminates the aquifer as shown in Figure 1 which shows chloride concentration in the groundwater aquifer in year 2015. Another quality problem is high concentration of nitrate in the agricultural areas in the north; the source of the nitrate ion in the groundwater chemical components has resulted from different sources i.e. intensive use of agricultural pesticides beside the existence of septic tanks to dispose the domestic wastewater in the areas where there is no wastewater collection system (Figure 2). The nitrate ion concentration reaches a very high range in different areas of the Gaza Strip, while the WHO standard recommended nitrate concentration less than $50 \mathrm{mg} / \mathrm{L}$ [1].

At its present rate of deterioration, the United Nations estimates that the underlying portion of the coastal aquifer on which the Gaza Strip relies for all its water needs will be unusable by 2016, and irreversibly damaged by 2020 [4] [5]. The lack of adequate supply of safe drinking water is therefore exposing the lives the Palestinians in Gaza to high levels of health risks. It has now become crucially important to safeguard available fresh water supplies and provide new additional potable water supplies to protect the lives and public health of the people in Gaza. As such, both short term and long term solutions to address the water scarcity issues have been formulated with particular em- 
phasis on reducing the dependency on fast deteriorating ground water aquifer sources, to seek new non-conventional water resource which in this case is limited to sea water desalination processes [6] [7].

Short-Term Low Volume (STLV) Sea Water Desalination Plant of $6000 \mathrm{~m}^{3} / \mathrm{d}$ is being under construction in the middle area of Gaza Strip. The plant will provide desalinated water for 75,000 inhabitants in Khanyounis and Rafah (Southern Part of Gaza Strip). The plant consists of water intake (four beach wells), Reverse Osmoses (RO) desalination system, and brine outfall and carrier pipeline to transmit the desalinated water to the blending tanks.

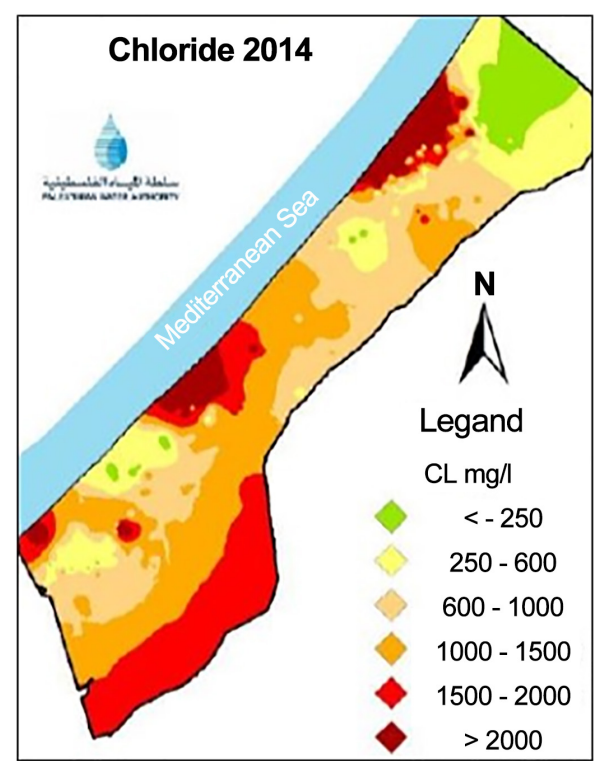

Figure 1. Chloride contour map 2014 [2].

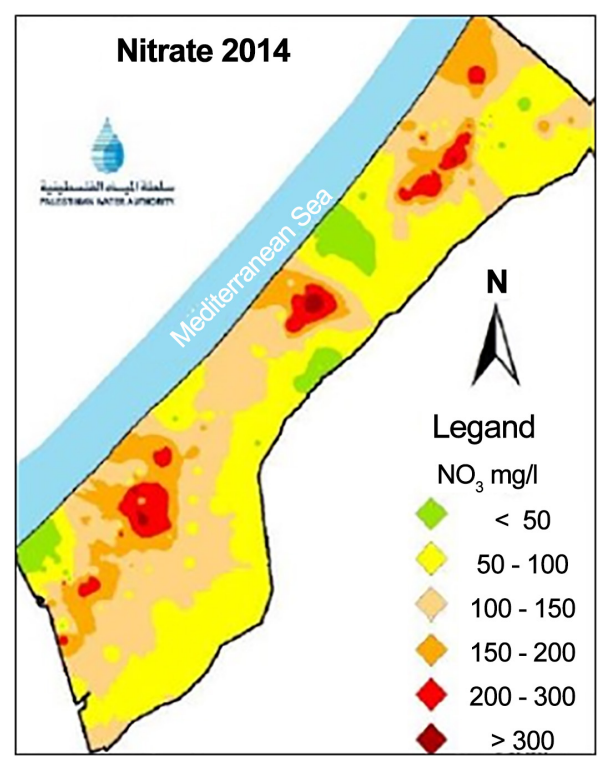

Figure 2. Nitrate contour map 2014 [2]. 
The limited number of analytical solutions for variable density flow problems creates a heavy dependence on numerical codes for simulating seawater intrusion. Such computer models have become irreplaceable tools to gain insight in real-world seawater intrusion issues ranging from system understanding on local or regional scales to future projections of SI for management purposes. Most codes solve a coupled system of variable density flow and solute transport equations, which is numerically complicated and computationally demanding. The main difficulty lies in the accurate solution of the solute transport part, which requires a fine discretization of the aquifer. Common techniques such as the finite element or finite difference methods perform well for the solution of the flow equations. The most widely used codes are SEAWAT [8]. SEAWAT was specifically designed for the simulation of SI, although it has many other applications as well, notably the combined simulation of groundwater flow and heat transfer. SEAWAT uses MODFLOW (finite differences) to solve the flow system and MT3D with its many solution techniques to solve the solute transport equations. Most MODFLOW packages are available in SEAWAT to simulate different stresses and boundary conditions [9].

This article will assess the impacts of water intake system on the aquifer. In case of negative impacts, mitigations measures will be addressed to minimize these negative consequences. The mean approach of this article is to use both MODFLOW and SEAWAT will investigate the impact of the beach wells on the seawater intrusion in the middle area of Gaza Strip.

\section{STLV and Beach Wells}

The STLV plant is located in Deir Al Balah Governorate, at the border with Khanyounis governorate, and will serve Rafah and Khanyounis governorates. 80 dunums have been allocated to this purpose from the Palestinian Land Authority (PLA) as shown in Figure 3. The feasibility study for the seawater intake option indicated that Beach Wells (BW) is the most feasible option for the STLV RO plant [10]. For this STLV plant with an intended capacity of $6000 \mathrm{~m}^{3} /$ day, the expected pumping rate of the beach wells is between 13,500 to $14,000 \mathrm{~m}^{3} /$ day. This number is calculated assuming a recovery rate of $48 \%$ and $3 \%$ for service water.

The number of beach wells was calculated based on the maximum quantity of water that can be pumped to serve the desalination plant which is a round $13,500 \mathrm{~m}^{3} /$ day. The total number of wells is 3 wells in addition to one standby well. Each of the three beach wells should have a capacity of pumping equal to $200 \mathrm{~m}^{3} /$ hour and should operate 24 hrs/day.

Based on the hydrogeological investigation carried out in the site the beach wells were allocated close to the shoreline to assure the pumping of seawater and not influence the groundwater aquifer. As shown in Figure 1 the four wells are located in one line parallel to the sea shoreline with a distance for 40 to 50 from the shoreline. The minimum distance between the wells is $40 \mathrm{~m}$.

Well components such as the screen diameter and length, gravel pack, the location of 


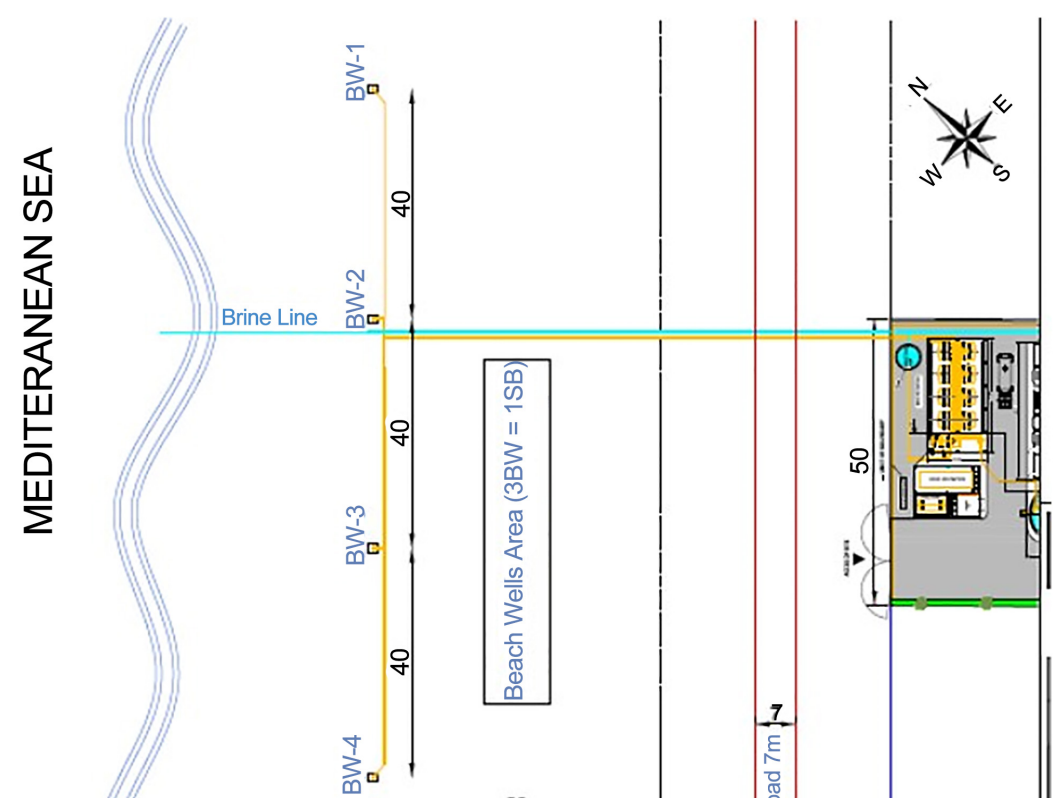

Figure 3. Desalination plant and beach wells site layout [10].

the screen, the location of pump, etc. were determined based on the preliminary design report and the hydrogeological investigation carried out by UG consultant. Figure 2 shows the description of the typical beach well that has the following characteristics:

1) The external diameter of the borehole is 20 inch.

2) The diameter of the screen is 14 inch, opening size is computed to retain $90 \%$ of the gravel pack, therefore, the opening size will range between $1 \mathrm{~mm}$ to $1.5 \mathrm{~mm}$ and the opening slot percentage is $35 \%$.

3) The length of the screen is $15 \mathrm{~m}$ located in sand or coarse sand layer below the water table. Stainless steel screens are used. The screen is located below the water table with a distance equal to double the expected drawdown of the water table after pumping of $200 \mathrm{~m}^{3} / \mathrm{hr}$. The shaft of the pump should be about between $8 \mathrm{~m}$ to $10 \mathrm{~m}$ below the groundwater table.

4) The total length of pump housing depends on the depth of the water table, the depth of permeable layers (sand aquifer) and the drawdown of the water table. The lithology indicates one layer of coarse sand (Kurkar) up to $45 \mathrm{~m}$ below the ground surface. The depth of the water level is 8 to $9 \mathrm{~m}$ below the ground surface. The beach wells screens are located inside the sand and kurkar layer. The exact depth of the screen will be designed considering maximum drawdown of the groundwater level. Figure 4 shows the location of the screen of the well which will be located between $30 \mathrm{~m}$ and 45 $m$ depth below the ground surface.

\section{Modelling Approach}

In order to study the impacts of beach wells on the aquifer, a prediction model, starting from the year 2000 until year 2040, was used to investigate the impacts of pumping from beach wells on the aquifer. Figure 5 presents the domain as a part of the coastal 


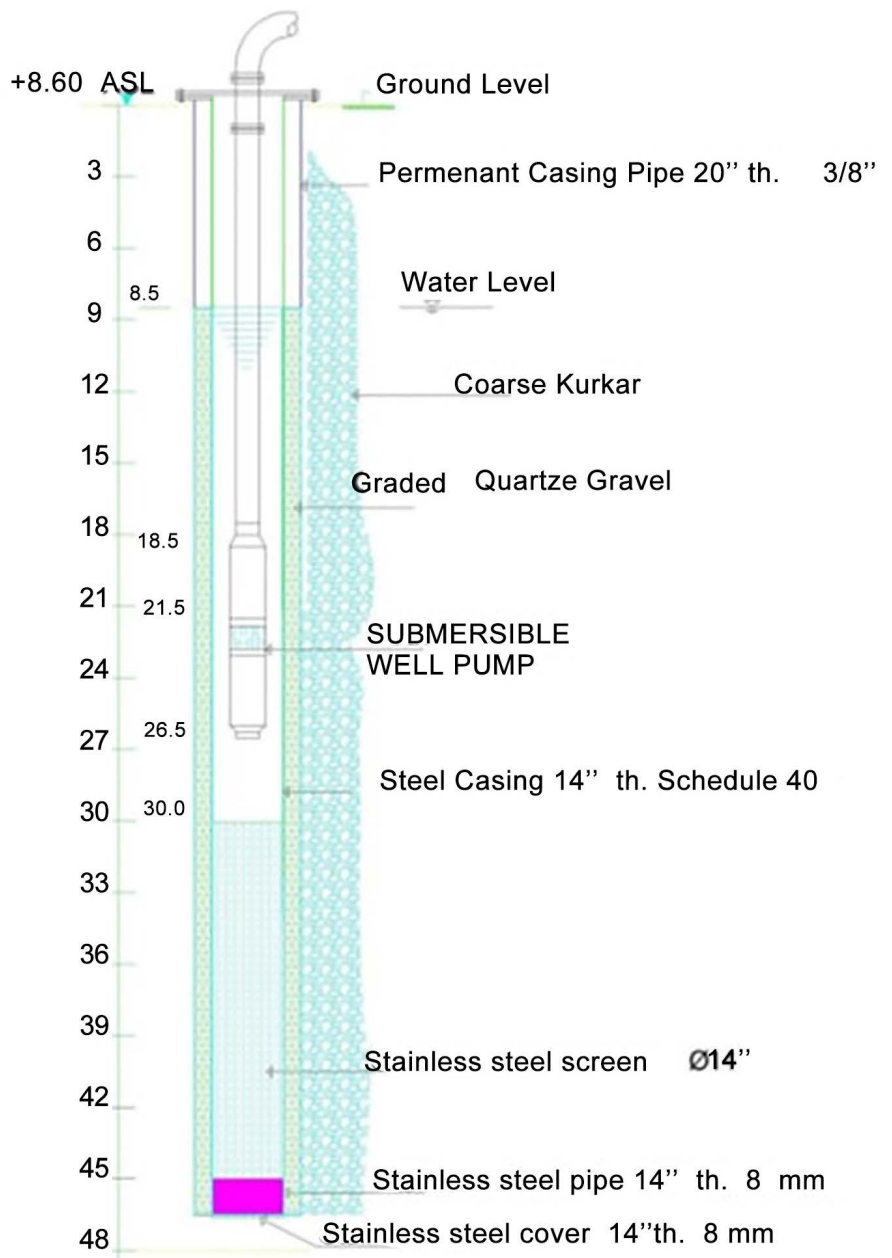

Figure 4. Beach well components [10].

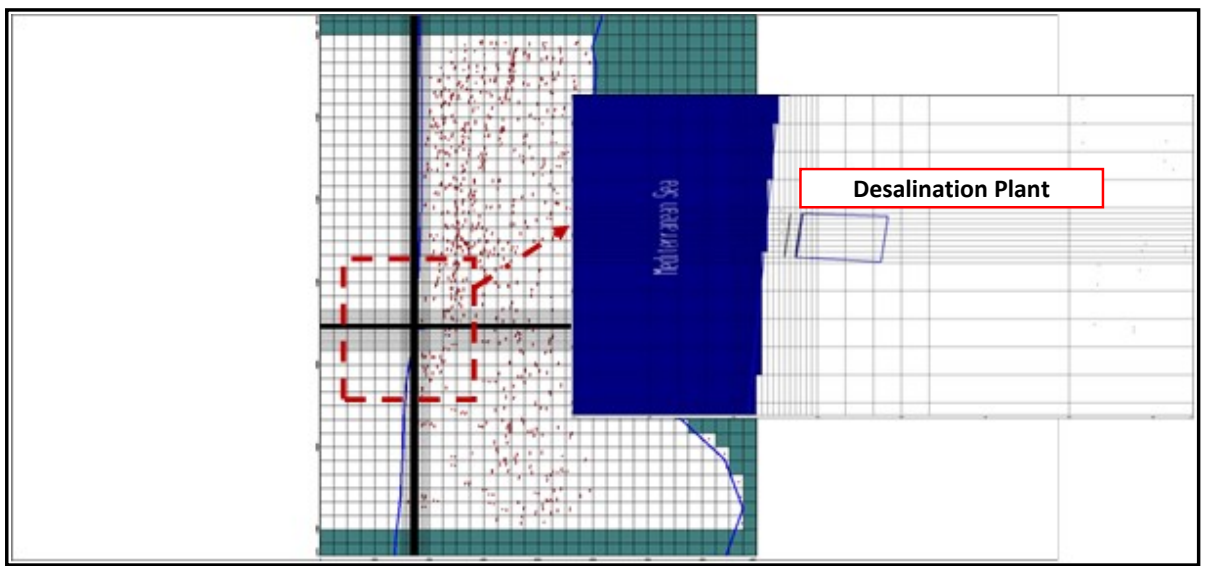

Figure 5. Groundwater model domain.

aquifer. Hence, the aquifer parameters were set as if they were in the transient model. The long term seasonal recharge rate for the summer and winter is considered to represent the seasonal differences in recharge through each year. In the projects area, 
the consultant does not find agricultural or monitoring wells which could be used a baseline for investigation the results of the model.

\section{Results}

\subsection{Impacts on Groundwater Quantity}

Based on the tests carried out during the design of the beach wells, it was reported that the groundwater level in the beach wells area is $0.08 \mathrm{~m}$ (MSL) [11]. Figure 6 shows the simulated groundwater level in the year 2015 before the operation of the STLV. Figure 7 shows the groundwater levels in year 2016 where there is a drop of $4 \mathrm{~m}$ of the groundwater in the beach well area. It seems that the drawdown in the beach well will become steady with the same amount after year 2022. This impact cannot be separated from the quality impacts. The steady four meter drawdown in the beach wells will force the flow from the eastern direction to the sea. This will have positive impacts on the aquifer since it will decrease the seawater intrusion to the aquifer.

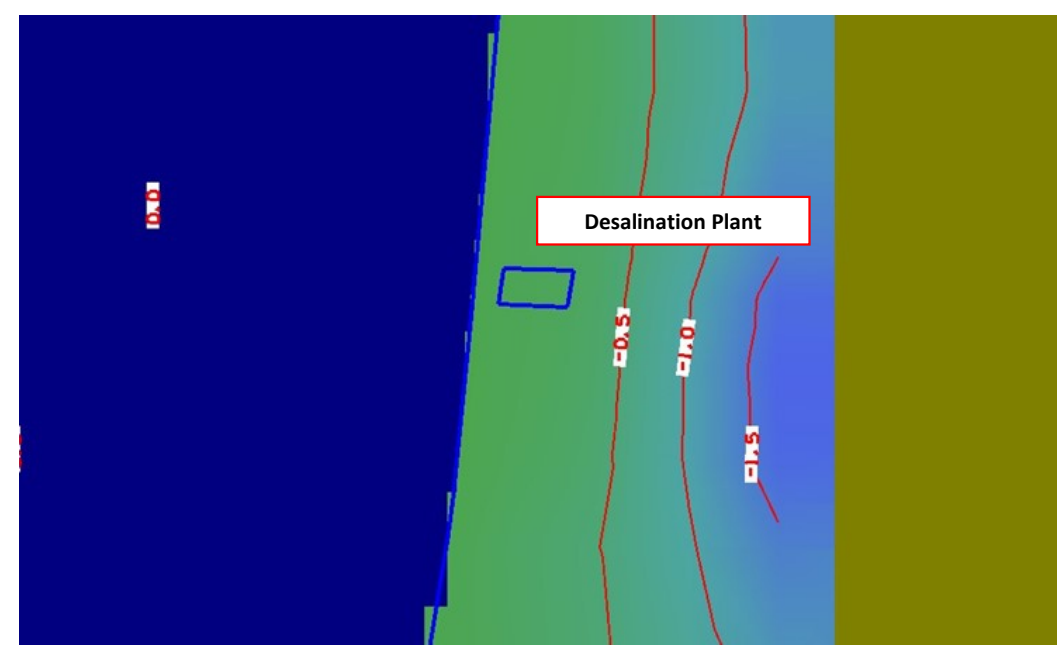

Figure 6. Groundwater level in year 2015.

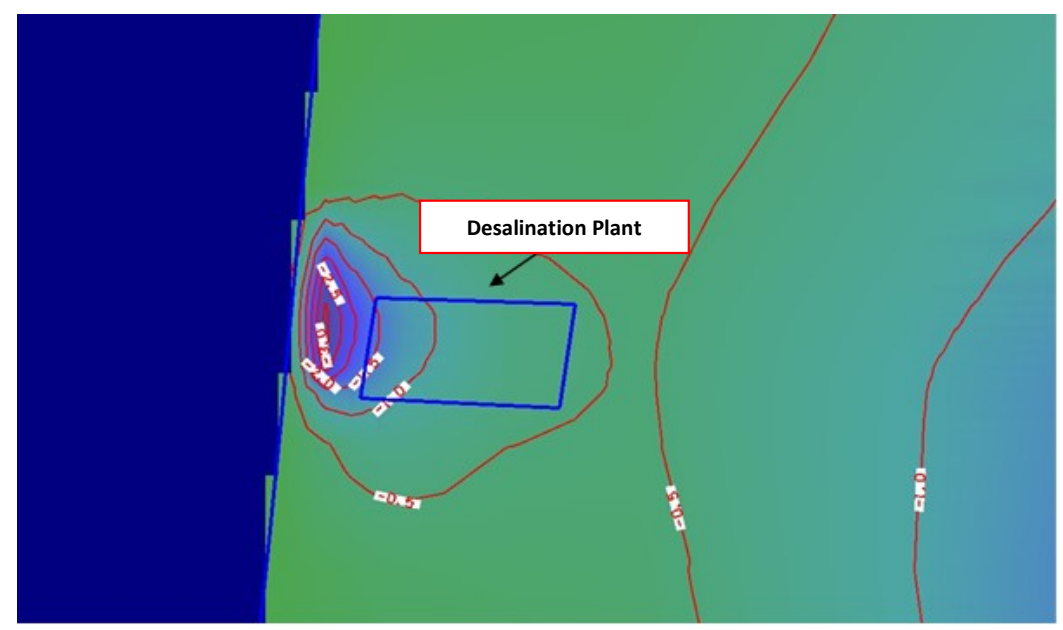

Figure 7. Groundwater levels in year 2016. 


\subsection{Impacts on Groundwater Quality}

The groundwater quality of an existing agriculture well (around $600 \mathrm{~m}$ in the eastern direction of the beach wells) was tested by the consultant. Table 1 shows the results of the water quality in this well. It can be seen that TDS is high which can be used as a baseline for monitoring the operation of the beach wells and how the beach wells can influence the groundwater quality. In addition these results can be used to check the groundwater quality modeling simulation and prediction as presented hereafter.

In order to study which part of the aquifer that will be directly influenced by the abstraction of sweater through the beach wells and to verify that the wells will continue abstracting sea water, transport due to advection-dispersion, density dependent flow SEAWAT module simulation has been performed using a pollution tracer which was considered as Chloride. The model also used to test the impacts of the beach wells on the aquifer water quality.

Figure 8 shows the simulated $\mathrm{Cl}$ concentration in years 2015 before the operation of the beach wells. The beach wells will be operated in year 2016. Figure 8 shows also that the $\mathrm{Cl}$ concentration $40 \mathrm{~m}$ from the sea shoreline has a concentration of 19,000 mg/l. This means the wells are abstracting seawater and do not abstract groundwater.

Figure 9 presented that the 3 beach wells will continue pumping of seawater with $\mathrm{Cl}$ concentration of $19,000 \mathrm{mg} / \mathrm{l}$. This proves that there will be positive impacts on the aquifer since the beach wells will continue abstracting seawater and are not abstracting groundwater.

Table 1. Groundwater quality of existing agricultural wells close to the beach wells.

\begin{tabular}{cc}
\hline Parameter & Value (mg/l) \\
\hline $\mathrm{TDS}$ & 14,000 \\
$\mathrm{Cl}$ & 7270 \\
$\mathrm{NO}_{3}$ & 13 \\
\hline
\end{tabular}

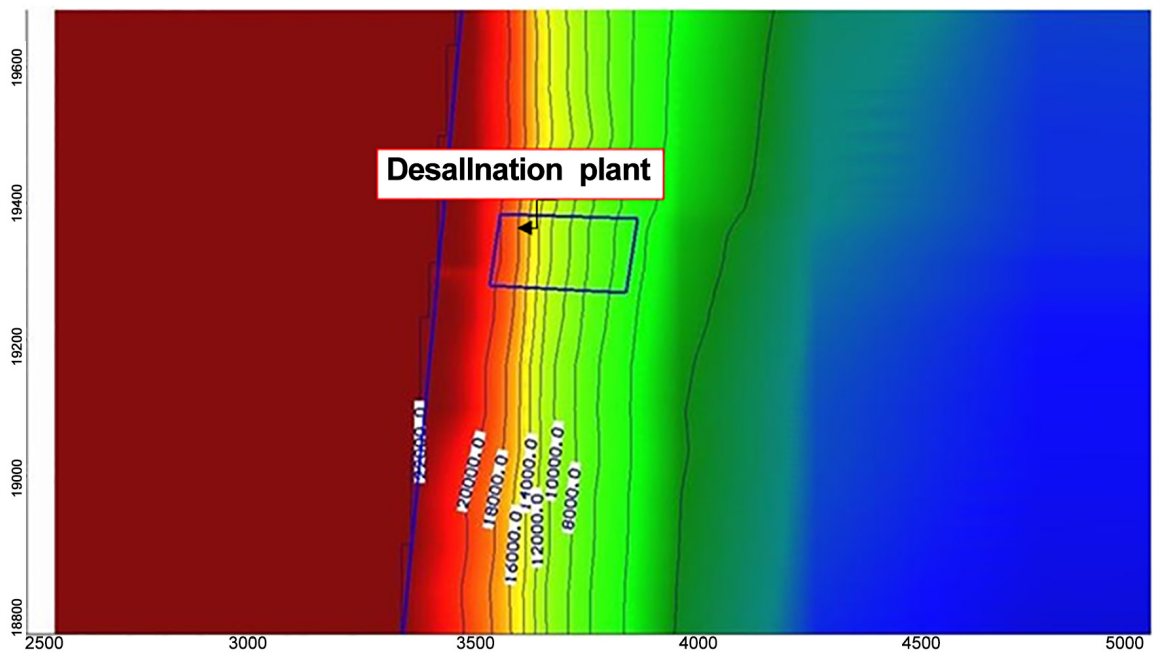

Figure 8. Simulated Cl concentration contours in year 2015. 
Figure 10 shows the predicted $\mathrm{Cl}$ concentration contours in year 2030 and, where, the beach wells will pump water with $\mathrm{Cl}$ concentration equal to $18,000 \mathrm{mg} / \mathrm{l}$. This means that the beach wells will accelerate the flow from the aquifer to the sea direction but still the pumped water is considered as seawater. This indicates the positive impacts on the groundwater aquifer since it will decrease and stop the seawater intrusion in the beach wells area (Gaza Strip Middle area).

Figure 11 presents the $\mathrm{Cl}$ concentration in aquifer cross section $(\mathrm{Cl}$ concentration varies depth) passing through the beach wells perpendicular to the sea and in year 2022. Figure 10 verify that screen of the beach wells which is located $45 \mathrm{~m}$ below the ground surface will pump water with $\mathrm{Cl}$ concentration of $19,000 \mathrm{mg} / \mathrm{l}$. Incase if the screen is deeper than 45, the $\mathrm{Cl}$ concentration will increase to reach 20,000 mg/l. Therefore, to increase the possibility of pumping sweater and reduce the impacts on the aquifer, it is recommended that the screen should be as deep as possible. The depth should be in the range of $50 \mathrm{~m}$ to $60 \mathrm{~m}$.

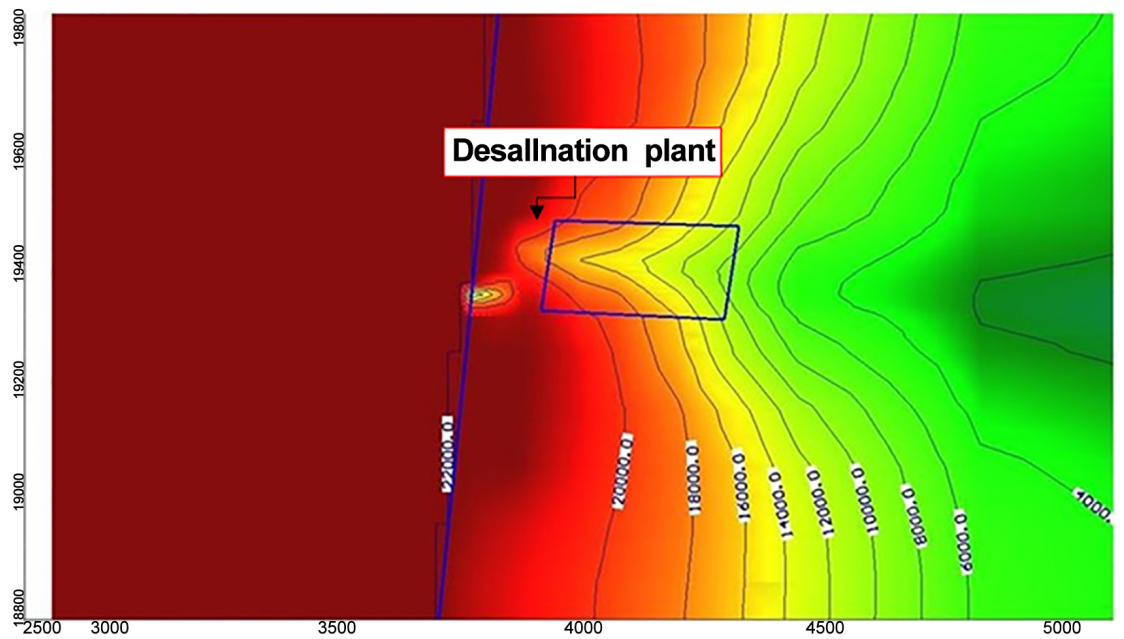

Figure 9. Predicted $\mathrm{Cl}$ concentration contours in year 2022.

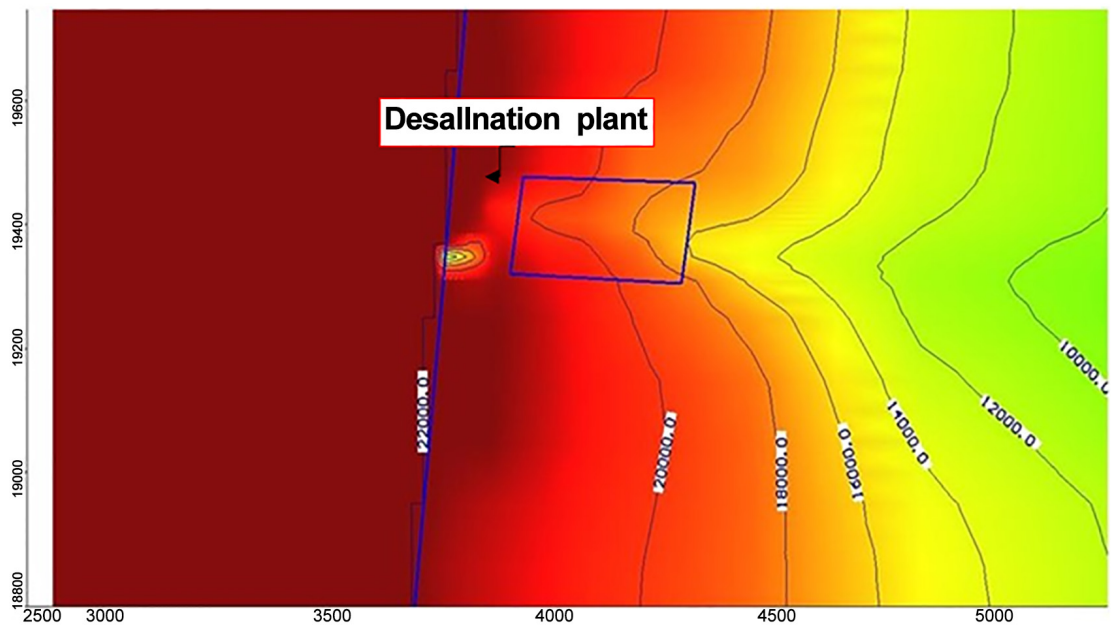

Figure 10. Predicted Cl concentration contours in year 2030. 


\subsection{Groundwater Aquifer Monitoring}

For small scale RO plants like the one in consideration of this study, beach wells were recommended for the intake. To assure the protection of the groundwater aquifer from any negative consequences due to pumping, it is very important to regularly monitor (monthly) the groundwater quantity (groundwater level) and quality (EC/TDS). Figure 12 shows the location of the proposed monitoring points.

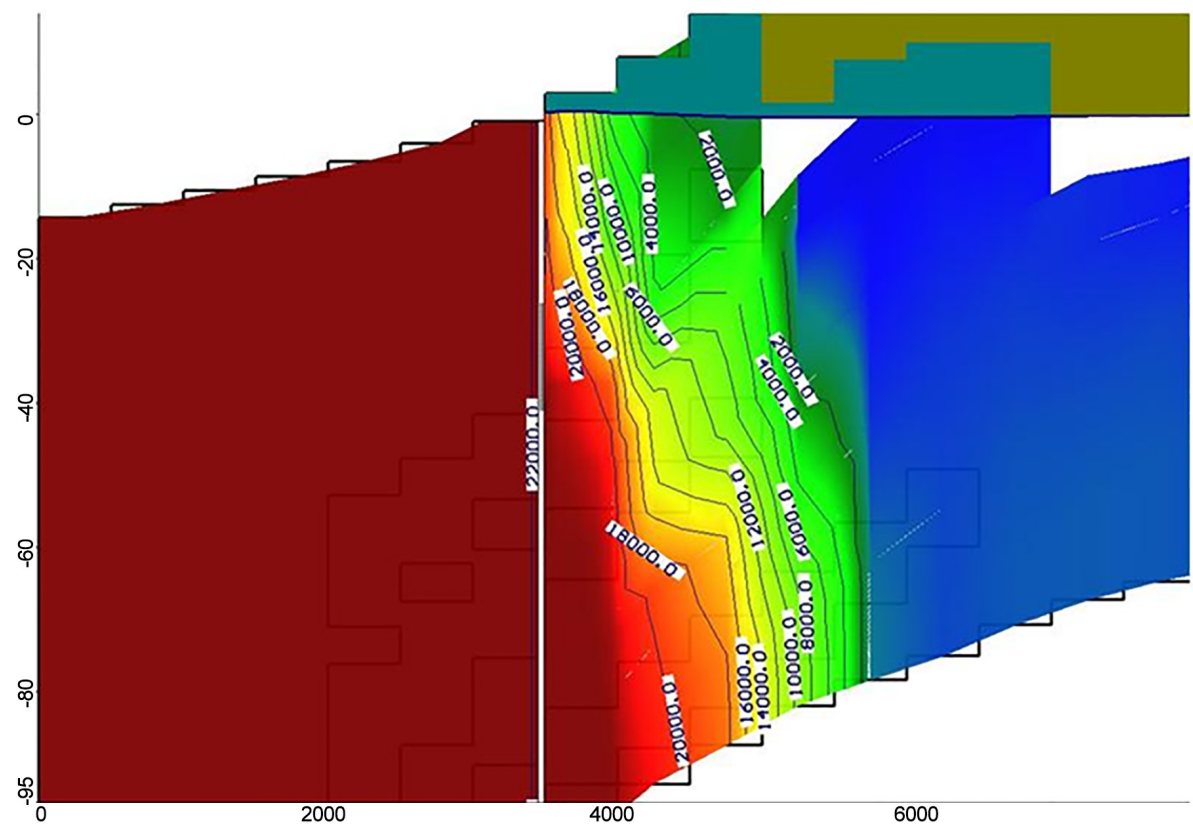

Figure 11. Predicted $\mathrm{Cl}$ concentration contours varies the depths of the aquifer (aquifer layers) in year 2022.

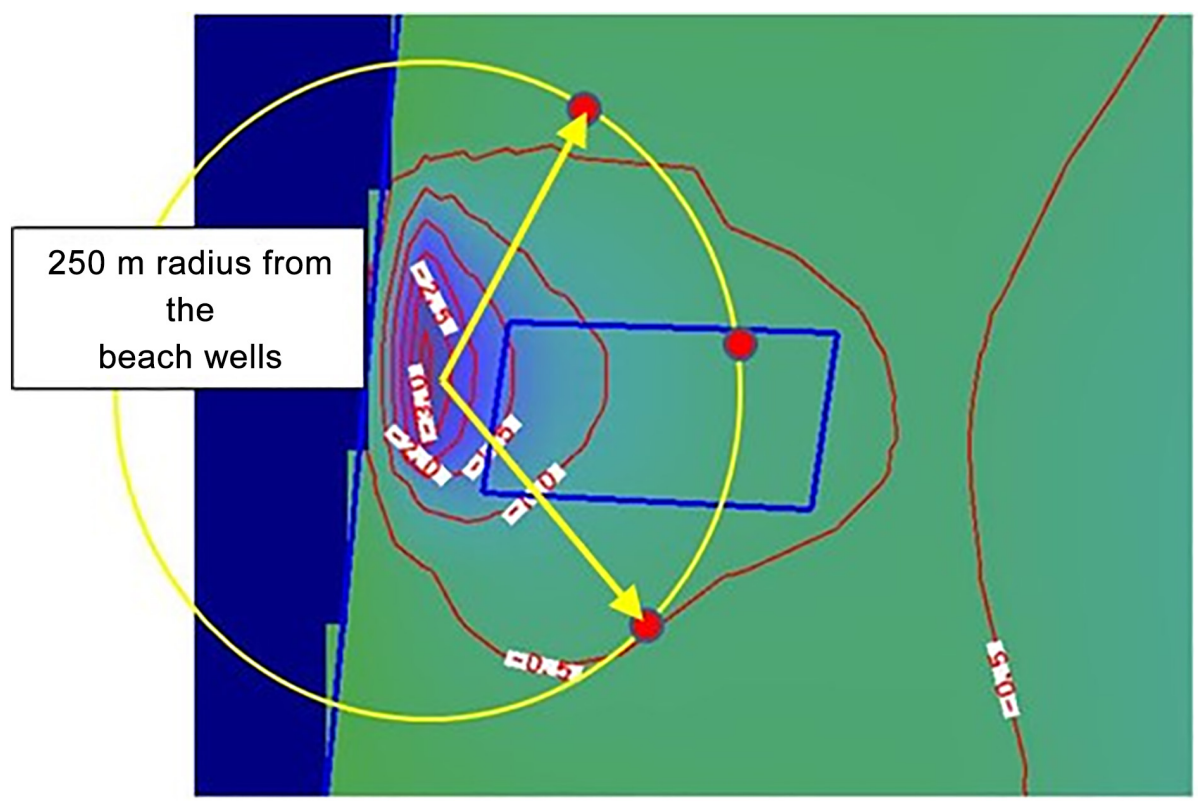

Figure 12. Groundwater monitoring points. 


\section{Conclusion}

The modelling approach used in this study showed that the location and the distribution of the beach wells are appropriate for the small size desalination plant intake. The article presented that the current distribution of the beach wells will have positive impacts on the Gaza Strip aquifer. The beach well will form a barrier for the seawater intrusion to the aquifer. However, for another case where the design criteria of the desalination intake will be changed, the impacts will completely be different. The essential criteria are the number of the wells, the distance between the wells, the well abstraction, the distance of the beach wells from the sea shoreline and the groundwater aquifer characteristics. This small desalination plant is of great importance for Gaza Strip, to face the population increase and the lack of clean and drinkable water resources in Gaza Strip. On other hand, these small desalination plants can enhance the groundwater quality in terms of reducing the seawater intrusion in Gaza Strip aquifer. The modelling approach is recommended to be used in investigating the impacts of future small scale desalination plants in Gaza Strip.

\section{References}

[1] CMWU (2015) CMWU Annual Report on Water Status in Gaza. Costal Municipalities Water Utility, Gaza, Palestine.

[2] Palestinian Water Authority (PWA) (2015) Water Resources Status Summary Report. PWA, Gaza, Palestine.

[3] Ismail M. (2003) Prospects of Water Desalination in the Gaza Strip. TRITA-LWR Master of Science Thesis, Stockholm.

[4] UN (2012) United Nations Country Team in the oPt, Gaza in 2020: A Livable Place? http://reliefweb.int/sites/reliefweb.int/files/resources/104094048-Gaza-in-2020-A-livable-pl ace.pdf

[5] UNEP (2009) Environmental Assessment of the Gaza Strip Following the Escalation of Hostilities in December 2008-January 2009. UNEP, Nairobi, Kenya.

[6] EMCC (2012) Environmental and Social Impact Assessment for Gaza Water Supply and Sewage System Improvements. EMCC, Gaza, Palestine.

[7] Mogheir, Y., Foul, A., Abuhabib, A. and Mohammad, A. (2013) Assessment of Large Scale Brackish Water Desalination Plants in the Gaza Strip. Desalination, 314, 96-100.

https://doi.org/10.1016/j.desal.2012.11.040

[8] Langevin, C.D., Thorne, D.T., Dausman, A.M., Sukop, M.C. and Guo, W. (2007) SEAWAT Version4: A Computer Program for Simulation of Multi-Species Solute and Heat Transport. US Geological Survey Techniques and Methods Book 6. US Geological Survey; Reston, $40 \mathrm{p}$ [Chapter A22].

[9] Werner, A.D., Bakkerd, M., Post, V.E.A., Vandenbohede, A., Lu, C., Ataie-Ashtiani, B., Simmons, C.T. and Barry, D.A. (2013) Seawater Intrusion Processes, Investigation and Management: Recent Advances and Future Challenges. Advances in Water Resources, 51, 3-26. https://doi.org/10.1016/j.advwatres.2012.03.004

[10] UG and Arterlia Consultants (2013) Preliminary Design for Short-Term Low Volume (STLV) Sea Water Desalination for Southern Governorates of Gaza Strip.

[11] S.A.A. (2002) Geotechnical Investigations for Gaza Desalination Plant Proposed Project Site. S.A.A. Geotechnical Engineering, Gaza. 
Submit or recommend next manuscript to SCIRP and we will provide best service for you:

Accepting pre-submission inquiries through Email, Facebook, LinkedIn, Twitter, etc.

A wide selection of journals (inclusive of 9 subjects, more than 200 journals)

Providing 24-hour high-quality service

User-friendly online submission system

Fair and swift peer-review system

Efficient typesetting and proofreading procedure

Display of the result of downloads and visits, as well as the number of cited articles

Maximum dissemination of your research work

Submit your manuscript at: http://papersubmission.scirp.org/

Or contact gep@scirp.org 